IJAPS, Vol. 14, No. 1, 27-55, 2018

\title{
RECONSTRUCTING AND REDEFINING HOKKAIDO DURING THE POST-WAR PERIOD
}

\author{
Juha Saunavaara* \\ Hokkaido University, Arctic Research Center, \\ Kita 21, Nishi 11, Kita-ku, Sapporo 001-0021, Japan \\ E-mail: juha.saunavaara@arc.hokudai.ac.jp
}

Published online: 15 January 2018

To cite this article: Saunavaara, J. 2018. Reconstructing and redefining Hokkaido during the post-war period. International Journal of Asia Pacific Studies 14 (1): 27-55, https://doi. org/10.21315/ijaps2018.14.1.2

To link to this article: https://doi.org/10.21315/ijaps2018.14.1.2

\begin{abstract}
The dominating and often contradicting tendencies of the early post-war Hokkaido were the continuing otherness, foreignness and distinctiveness from the rest of Japan, and the growing integration into the nation state. In other words, Hokkaido became more tightly connected to and more a part of Japan than ever before, but it clearly retained its peculiarity and was not simply a region or prefecture among the others. This study of Hokkaido is built on the premise that rather than being ahistorical and unchangeable entities, regions can be considered as spatial manifestations of social processes and they have to be conceptualised and analysed empirically as a part of the historical development of the society. It utilises the institutionalisation of region model when analysing how a region is constructed and how it is connected to the observable political, legal, social, economic, cultural, educational and administrative practices. The model consists of four interlocked stages (territorial shaping, symbolic shaping, institutional shaping, and establishment of region) that can be abstracted for analytical purposes and is tested here as a device to perceive the importance and understand relations between the various processes contributing to the making of the region.
\end{abstract}

Keywords: Region, institutionalisation, identity, Hokkaido, Japan

The concept of a region has become an important catchphrase in academic and political discourse during the past decades. Instead of being stable spatial territories with fixed identities or ahistorical and unchangeable entities, regions 
are conceptualised as social and historical processes and as socially constructed objects, the meanings and characteristics of which are in continuous flux (Garcia-Alvarez 1998: 117-128; Paasi 2009: 121-141). Meanwhile, questions concerning the characteristics and the future of different (mainly rural) regions in Japan have attracted a growing attention. This is undoubtedly due to the long-lasting processes of urbanisation, capital and technology intensive industrialisation and aging society contributing to regional shrinkage and sudden events such as the crisis succeeding the great Tōhoku earthquake and tsunami that shook the very foundations of local societies.

While the studies concerning the past, recent or current developments in Japanese regions have successfully observed the origins and consequences of various changes, they have not necessarily been peculiarly theory-oriented. In other words, they have often failed to recognise the processes through which regions are constructed and understand how they are connected to the observable political, legal, social, economic, cultural, educational and administrative practices. One of the most advanced attempts to solve these questions among geographers is provided by Anssi Paasi's model built around the institutionalisation of regions. This model considers regions as spatial manifestations of social processes, and emphasises that regions have to be conceptualised and analysed empirically as a part of the historical development of the society. It describes institutionalisation as a process during which some specific level of the spatial structure becomes an established entity, which is identified in different spheres of social action and consciousness and which is continually reproduced in individual and institutional practices (Paasi 1986).

This study concentrates on Hokkaido and utilises the model of the institutionalisation of the region to analyse the reconstruction and redefinition process of the region during the decades following Japan's defeat in the Second World War. During those years, the northernmost island of Japan encountered drastic changes both in its internal and external conditions. The increase in its population with the inflow of new people from lost colonies and from devastated areas in central and southern Japan, and the outflow of Korean and Chinese forced labourers, new administrative structures, its altered position in the structure of the Japanese economy — which was experiencing a major readjustment - and, for example, adaptation to the new geopolitical position, were all factors challenging the definitions and shared understanding concerning a region which was less than 100 years old. In other words, the model that decomposes the concept of region analytically into pieces which characterise its historical and social nature, is utilised here to illuminate the complex and rarely studied circumstances of post-war Hokkaido. It is, however, assumed 
that the usability of the model is not limited to the mentioned spatial and temporal context. On the contrary, previous attempts to utilise this model in various non-Asian contexts, seem to speak on behalf of its flexibility and wide applicability (Garcia-Alvarez 1998; Hamin and Marcucci 2008; Jaakson 2000; Macleod 1998; Metzger 2013). Despite the incorporated structural elements, the model is not as mechanical as it may appear at the first glimpse and it does not force the complex processes to fit into an oversimplified mould.

The model introduces four stages that can be abstracted for analytical purposes from the process of the institutionalisation of regions. This does not, however, mean that these stages (territorial shaping, symbolic shaping, institutional shaping, and establishment of region) would necessarily follow each other or that their order would be pre-determined. In fact, in most cases, various processes occur simultaneously. The model also leans on a concept of regional identity which is to weave elements that have become significant in the institutionalisation process together. This concept can still be deconstructed to consist of both the regional identity of the inhabitants, or regional consciousness referring, for example, to the feeling of togetherness and the shared idea of and identification with community, and the concept of the identity of a region. The former does not, however, automatically refer to the existence of a unisonous Hokkaido or imply that all the people in Hokkaido would have shared same ideas and conceptions. On the contrary, the very foundations concerning the understanding of the history and meaning of the region of the indigenous Ainu people, for example, differed greatly from those of the majority. ${ }^{1}$ While recognising the need to address the Ainu when discussing the history of Hokkaido, this study does not focus on Ainu. The question of the past and present of the indigenous people of Japanese archipelago (northernmost Japan), the Kurile Islands and part of Sakhalin Island have already inspired several excellent studies. It can even be claimed that this topic dominates Hokkaido-related research literature published in Western languages.

The identity of region refers to the images held either by the local inhabitants or those living outside the region. It points to those elements of nature, culture and people that are used in the discourses and classifications of science, politics, cultural activism, regional marketing, tourism, governance and political or religious regionalisation. The aim of such classifications is often simply to distinguish one region from others (Paasi 1986: 131-138; Paasi 2009: 121, 134-136, 140-141).

Finally, when discussing the peculiarity of Hokkaido, I make comparisons between this region and the rest of Japan. However, I am not 
suggesting that the rest of Japan would form or would have formed one entity without variations. Obviously, there are also other regions with peculiar characteristics (Okinawa can be mentioned as the most evident example). In fact, one could claim that all regions are somehow unique. Therefore, these comparisons are to be understood as practical means to demonstrate differences between Hokkaido and what was considered typical or distinctive to the early post-war Japan.

\section{DETERMINING THE TERRITORIAL SHAPE OF HOKKAIDO AFTER THE DEFEAT}

Territory and borders limiting it form the most tangible aspect of a region and a suitable starting point for the analysis of the institutionalisation of regions. While Hokkaido as an island may appear to be a territory with an unambiguous definition, the process leading to an assumption of its territorial shape has been anything but straightforward. In fact, the territorial shape of Hokkaido is an unsettled question even today. Namely, most of the Japanese maps describing the territory of Hokkaido include the disputed islands of Kunashiri, Etorofu, Habomai and Shikotan, located northeast of Hokkaido and occupied and administered by Russia, just as they include, for example, the small islands of Rishiri and Rebun, ${ }^{2}$ the status of which, as inseparable part of Japan and Hokkaido, is not questioned.

The first stage of the institutionalisation model assumes that the existence of a region always draws on a certain territorial shape that emerges along with history or is simply decided ad hoc. It refers to the development of the social practices through which the region achieves its boundaries and will become identified as a distinct unit in the spatial structure of the society. The boundaries may, however, change and the territorial shape of a region at a given time does not necessarily disclose very much about its past. Therefore, it is important to be aware of the history of such boundary changes, as expectations and conceptions concerning the region can comprise elements which appear not to belong to that region at the time but which may have previously been part of it. The existence of boundaries as a basis for social classification is also considered a requirement for the emergence of a regional consciousness among inhabitants (Paasi 1986: 124-125; Paasi 2009: 134). When deconstructed into the form of research questions, the model guides one to ask: through which kind of processes was the conception or idea concerning the territory of Hokkaido born and produced at the beginning of the post-war 
period; how widely was this conception shared among the Hokkaido people and did it differ from the ideas upheld outside the region; and how have the new boundaries challenged the historical conception concerning the scope of the territory.

Hokkaido's status as a territorial entity has changed greatly during the past 200 years. The area inhabited by the Ainu, or at least the southernmost parts of it, gradually became incorporated into the Japanese cultural sphere during the Tokugawa-period (1600-1854). A major player in this process was the Matsumae clan, which enjoyed formally institutionalised exclusive rights to trade with the Ainu until the end of the 18th century. The need for a new kind of approach emerged, however, when the activity of the Western Powers around the island awakened the Tokugawa Shogunate in Edo-modern day Tokyo-causing it to strengthen its presence in the North (Irish 2009: 52-54; Walker 2001: 37-41, 97-98, 126-127, 175-176, 227-228).

In 1868, approximately a decade after the Western Powers had forced Japan to open its ports and accept many unequal treaties, the domestic restlessness led to a civil war. After the dethronement of the Tokugawa administration, a new ruling elite acting in the name of the Emperor emerged. While the northern island was not at the centre of the so-called MeijiRestoration, it acted as a stage for the final act of the civil war. The effects of the reforms that transformed Japan from a feudal agrarian society into a modern industrialised nation state during the second half of the 19th century were, however, strongly felt in Hokkaido, which officially became a part of the territory of Japan from 1868 onwards. In fact, Hokkaido has been called modern Japan's first foreign conquest and its incorporation into the territory of Japan is sometimes referred to with the term and concept of "domestication" (Blaxell 2009; Irish 2009: 77-83, 97-105).

The immigration promotion activities were an example of policies dealing especially with Hokkaido. One reason behind the emerging interest in the increase in Hokkaido's population (Japanese or Waijin population, not the number of native Ainu) was connected with the eastward expansion of Russia. The treaty that had been agreed between the two states in 1855 placed the demarcation line in the middle of the Kurile Island chain, ${ }^{3}$ between Etorofu and Uruppu. The new treaty of 1875 resettled the border with Russia by stating that Sakhalin belonged to Russia and all the Kurile Islands belonged to Japan. While the Treaty of Portsmouth at the end of the Russo-Japanese War (19041905) affected the status of southern Sakhalin, the territory of Hokkaido was later contested only after Japan's defeat in the World War II (Bukh 2010: 51, 54; Irish 2009: 82, 116). 
Contrary to Germany, the defeated Japan was not divided between the victorious Allies and Hokkaido remained an inseparable part of the territorial entity under the predominantly American occupation. Thus, the plan of the Soviet Union to take over Hokkaido as its own occupational zone did not materialise. The Soviet Union had joined the war against Japan on 9 August 1945 and rapidly occupied vast areas, including the Kurile Islands, which had been under the rule of the Japanese Empire. During the war, the American planners of post-war East Asia had argued that Japan had a strong claim to the southern group of the Kurile Islands on the basis of nationality, selfdetermination, geographic propinquity, economic need and historic possession and recommend that they should be retained by Japan. ${ }^{4}$ However, the Kurile Islands and Southern Sakhalin were mentioned in the Yalta Conference as a territory which the Soviet Union was to receive in exchange for participation in the war against Japan. The Potsdam Declaration stated in June 1945 that Japanese sovereignty was to be limited to four named main islands, but referred also vaguely to other minor islands. The exact definitions concerning nationality and territory caused problems for the occupation authorities at the beginning of the occupation, for example, in questions of reparations and elections. The confusion of the autumn of 1945 was solved when the occupation authorities defined the area over which the Japanese Government held governmental or administrative authority on 29 January 1946. On this occasion, the Kurile Islands were excluded (Bukh 2010: 56-57; Compel 2006).

This did not, however, prevent the outbreak of various grassroot movements in Hokkaido demanding the return of the Soviet-occupied territory almost immediately after the war. Nemuro, which is the region geographically closest to the lost territories and where most of the former residents of the islands resettled, became the focal point for such activities. While some groups demanded the return of all of the Kurile Islands, others focused on the islands of Kunashiri, Etorofu, Habomai and Shikotan, or strove only for the restitution of the latter two mentioned. The other end of the spectrum was formed by those longing also for the return of Southern Sakhalin. Besides the geographical scope of the territory, these groups had divergent objectives reflecting the, predominantly economic, interests of their members. Some of the groups were formed by individuals who had escaped or been deported from the Soviet-occupied territories whereas others included those who had vested interests related to the territory. Therefore, some movements were interested in the islands per se, whereas others emphasised the waters surrounding the islands as a source of fisheries. The methods through which these groups attempted to achieve their objectives reached from petitions to the occupation 
authorities and the Japanese government to the organisation of rallies (Bukh 2010: 57-58; Bukh 2012: 483-509).

While the heightening of Cold War tensions between the US and the Soviet Union made the international climate challenging for any settlement, the Kurile Islands did not disappear from the political agenda in Hokkaido. Besides the small civic society organisations, the Hokkaido prefectural government - under the leadership of socialist Governor Tanaka Toshifumi-became active from 1950 onwards. The main factors contributing to the decision of the Tanaka administration to engage in the territorial issue were the fear that the central government might give up the Soviet-occupied territories during the peace settlement, perception concerning the economic importance of the islands for the development of Hokkaido, and a conflict between the conservative central government and a socialist governor who utilised the territorial conflict as a platform to criticise the leaders in Tokyo. Furthermore, the issue of desired policy regarding the settlement of the territorial dispute became entangled with party politics in Hokkaido (Bukh 2012: 491-492).

A major settlement was achieved at international level in 1951 when Japan renounced its rights to Sakhalin and the Kurile chain in the San Francisco Peace Treaty, which was not signed by the Soviet Union. However, the exact geographical scope of the Kurile Islands was not defined in the treaty, just as it had not been defined at the Yalta summit. Japan kept persistently demanding the return of the four southernmost islands, arguing that they did not constitute part of the territory it renounced in the Peace Treaty. Although the agreement made led to anti-government mass demonstrations, activists in Hokkaido were not united. Many of the local groups in Nemuro criticised the Hokkaido Government for running its own movement with political aims. In addition to this, Nemuro city's stance toward territorial conflict differed from that of the prefectural government. What the local people urgently wanted, was a treaty enabling safe fishing activities in the nearby waters. In exchange, they were ready to be satisfied with the return of Habomai and Shikotan (Bukh 2010: 59; Bukh 2012: 488, 490, 493-495).

When the news concerning a two-island agreement with a swift resolution of fisheries-related issues were reported during the Soviet-Japanese talks in 1955, it was warmly welcomed among many Hokkaido people and local organisations. As the peace treaty negotiations continued, confidence concerning the restitution of part of the lost territory rose in Hokkaido and the prefectural administration even established a new department to plan the reconstruction and development of the territories to be returned (Bukh 2010: 59; Bukh 2012: 488, 490, 493-495). However, this kind of optimism 
turned out to be premature. The Japanese Government was not united in its stance toward the settlement based on the reversion of two smaller islands. Furthermore, the US Government's opposition to the plan is also mentioned as a factor complicating the negotiation process (Togo 2005: 234-236).

Eventually, the Soviet-Japanese talks did not lead to a peace treaty and the role of the territorial dispute as a key political issue in Japan diminished. The Hokkaido Government-based deviations from the state policy came to end as well when the candidate representing the ruling Liberal Democratic Party (LDP) was elected as the new Governor of Hokkaido in 1959. While general interest in the area-referred by the term "Northern Territories" despite their location east of Hokkaido-decreased in the 1960s, the role of local Hokkaido-based actors with a pragmatic rationale declined and the territorial dispute became a national-level political issue (Bukh 2010: 59-61; Bukh 2012: 495-499).

The Hokkaido-based discussion concerning the territorial sphere of Japan was not limited to the future of the Kurile Islands. Nevertheless, despite many similarities — such as the significant role of the repatriates who had mainly resettled in Hokkaido, the relation to regional politics in Hokkaido, and the question of access to the former fishing grounds - the debate concerning Southern Sakhalin or Karafuto seems not to have involved discussion about the territorial borders of Hokkaido. Rather, the area was considered an independent Japanese regional entity, the history of which as a settler colony had a great resemblance to that of Hokkaido. Therefore, the role of a proxy site of memory for Karafuto-which Hokkaido assumed during the post-war decades - is understandable (Bull 2013: 133-149; Bull 2015: 63-79; Seaton 2015: 119-140).

The questions concerning territorial shape in early post-war Hokkaido can also be approached as an internal issue. Within this context, the process of deinstutionalisation of a region, referring to a situation where a region ceases to have official status in the regional system or in the broader social consciousness, becomes topical (Paasi 1991: 243; Zimmerbauer et al. 2012). Hokkaido's existence as a one united administrative entity was challenged in the mid-1950s. On 20 October 1955, the Investigation Special Committee of the conservative Democratic Party of Japan, also including Hokkaido-based politicians, set out an argument calling for the split of Hokkaido- which was a giant among the existing prefectures as far as the acreage was concerned-into five prefectures with prefectural capitals in Sapporo, Asahikawa, Hakodate, Muroran and Kushiro (Fujino and Asada 1982: 76-79). 
While the conservatives also initiated a competing proposal dividing Hokkaido into six prefectures, the administration of Governor Tanaka strongly opposed these plans. Most of the Hokkaido newspapers were also against the plan to divide the existing prefecture, but it had its supporters in Hokkaido. This movement was based on anti-Sapporo emotion that was centred in Asahikawa and surfaced from January 1950 onwards. At that time, representatives of various regions in Hokkaido gathered in Asahikawa to establish an association striving for the division of Hokkaido into four prefectures. This movement resisted the fact that Hokkaido's development, administration and economic activities were strongly concentrated in Sapporo - the rapid post-war growth of which paralleled the development of such urban areas as Tokyo, Yokohama or Nagoya. The disappearance of the proposal from the political agenda was not, however, due to local resistance or a lack of support, but rather because of changes in the political conditions in the centre-within the dominating LDP, which was established at the end of 1955 (Fujino and Asada 1982: 72, 76-79; Hiraku 2011: 223-227).

It should be emphasised that the criticism concerning Hokkaido's position as a prefecture did not unambiguously diminish the significance attached the region itself. On the contrary, the supporters of the division plan argued that such action was needed to secure the effective development of a Hokkaido which was highly dependent on government subsidies. Furthermore, the fact that Hokkaido was governed by a socialist governor at the beginning of a post-war period, may also explain why the representatives of the conservative central government would have been ready to the split the prefecture or place Hokkaido under the government's direct control with special administration including a nominated Governor (Fujino and Asada 1982: 78).

\section{EVOLUTION OF TERRITORIAL SYMBOLS}

Hokkaido was born on 15 August 1869 when a group of political leaders in Tokyo decided that the island north of Honshu, which had previously been known as Ezochi- "barbarian land"-would be renamed Hokkaido (Mason 2012: 24, 26; Seki 2006: 25-92). The process of naming, on the other hand, is an example of the symbolic shaping that forms the second stage in the institutionalisation of regions model. During the formation of the conceptual or symbolic shape of a region, certain structures of territorial symbols become established. Although the meanings associated with them will always be constructed individually, these symbols-expressing and strengthening the 
idea of the existence of a specific region and regional identity-canonise an apparatus for distinguishing the region from all others (Paasi 1986: 114, 125130; Paasi 2009: 135). But what are these symbols?

With regard to regions, territorial symbols are usually more or less abstract expressions of group solidarity embodying the actions of political, economic and cultural institutions and so on. On the other hand, nature is often transformed from being just a basis for material production, exchange and consumption, to a more abstract manifestation in the form of a landscape. Landscapes thus become parts of the iconography of "regionhood" and they can be canonised along with other signs of the physical world and symbols of the human world. Besides the stereotypes concerning environment, the symbolic shape may also consist of ideas concerning the characteristics of the population. As far as the actions of the inhabitants of a given region are concerned, the symbolic shaping is manifested in the emergence of organisations and associations which make use of the territorial symbols of the region in their names and actions. Namely, the spatial diffusion of the network of associations carrying the name of a given region is considered a good indicator of the level or regional consciousness. The same can be said of companies, which employ specific territorial symbolism as an indicator of a common identity and of the limits of their market areas (Paasi 1986: 114, 125-130; Paasi 2009: 135).

"Hokkaido" had appeared in the names of administrative units and private businesses before and during the war, but the early post-war years witnessed the emergence of important actors symbolising the unity of the region and its distinguished position. The Hokkaido Development Agency and the Hokkaido Development Bureau-discussed in detail on the coming pages - were examples of official institutions strengthening the idea of a region administered and developed as an independent entity. It should be remembered that the appearance of "Hokkaido" in the names of such organisations could not be regarded as a truism. Namely, during the process that eventually led to the establishment of the post-war Hokkaido development system, the occupation authorities once particularly ordered the word "Hokkaido" to be dropped from the name of the new committee contributing to the development of the region (Saunavaara 2014). Although a detailed analysis of the enterprises and corporations including "Hokkaido" in their names during the early postwar period is omitted this time, examples such as Hokkaido Bank (Hokkaidō Ginkō) as a major regional credit institution, Hokkaido Colliery \& Steamship Company (Hokkaidō Tankō Kisen) as a subsidiary of the Mitsui zaibatsu, and 
Hokkaido Butter (Hokkaidō Bataa) first as a company and then as a nationwide brand representing the local agriculture, can be mentioned.

Hokkaido, among other prefectures, gained many official and concrete symbols in the 1960s and 1970s in the form of a bird, tree, song, flower, and type of physical exercise of the prefecture (Hokkaidō 2016). However, their visibility and recognisability remained modest when compared with the flag of Hokkaido enacted in 1967. Despite being a new symbol, the flag drew from regional history and made a strong reference to the past through the pictorial motif of a red star against a blue background. The new flag, in other words, renewed the theme of the flag of the Kaitakushi or the Bureau of Colonial Affairs dating back to the Meiji-period (Hokkaidōjin 2016; Irish 2009: 164$165)$.

Just as the institutionalisation model suggests, next to these officially recognised symbols, a peculiar iconography consisting of symbols inseparably connected to the landscape and people of Hokkaido developed. Some of the strongest examples of the existence of such emblems can be seen in the works of graphic designer Kuriyagawa Kenichi, who was born and raised in Hokkaido. Kuriyagawa's tourism posters including icons conveying the wide image of Hokkaido won fame and reached wide audiences around Japan during the early post-war decades. While some of the posters were ordered by local actors and advertised attractions of the given location, Kuriyagawa also produced an array of pictures with a plain text reading "Hokkaido" on them. These posters illustrated a region with distinguishing characteristics. Besides the snowy mountain landscapes, making reference to the cold climate, Kuriyagawa's posters repeatedly portrayed symbols — such as animal husbandry, the dairy industry, pasture land, western agricultural machinery and clothing - referring to a form of landscape and agriculture that was typical for Hokkaido but differed from the rest of Japan (Kamata 2012: 51-53, 77-99, 152-154). Therefore, these posters, together with the cover picture of Nagai Yōnosuke's and Okaji Ichirō's book, entitled Hokkaidō (1962), for example, can be considered a continuation of the tendency to present Hokkaido as an image of the American-type frontier which carries the popular notions of vast lands of freedom and independence. An early example of the custom to equate Hokkaido with the American frontiers can be found in the illustration of the Hokkaido Colonial Magazine published in 1880, i.e., already several years after the American style agriculture and architecture had been promoted in Hokkaido under the command of Horace Capron who was an advisor of the Bureau of Colonial Affairs born in Massachusetts. (Nagai and Okaji 1962; Day 2012: 25-26, 66; Irish 2009: 145-148). 
The "factual correctness" of the message conveyed through these pictures cannot be denied. Hokkaido has been, and still is, a major production area for dairy products in Japan, and the Milk Land Hokkaido (2016) campaigns boosting the consumption of milk in Japan continue to feed this image even today. However, this discourse hides the fact that Hokkaido - which was and, allegedly, still is viewed as the northern frontier of Japan with a deep-rooted sense of otherness (Day 2012: 12, 25-26; Hansen 2014; Nagai and Okaji 1962: 235) - has gradually become a major production area for one of the strongest symbols of Japanese culture, land and identity, namely rice (Blaxell 2009; Ōnuma 2004: 9-41). While rice and rice cultivation in paddy fields may appear as the ancient symbols of Japaneseness, the notion of Japan as a unique rice culture has remained a common and omnipresent theme in Japan (Blaxell 2009; Hansen 2014: 56-57). In fact, many early writers of the Nihonjinronliterature on Japaneseness which emphasises Japanese uniqueness and homogeneity and gained popularity in the late 1940s and 1950s onwardsexplained different cultural patterns, the group-oriented nature of society and the highly communal way of life through rice cultivation that had required cooperative labour among Japanese (Morris-Suzuki 1995: 776; Siddle 2014: 19; Yoshino 2004: 249-251).

Despite the severe challenges caused by the climatic conditions, the history of attempts to cultivate rice in Hokkaido is tightly bound to the history of state-led reclamation and development policies. Therefore, the decision not to illustrate the attempts and achievements with regard to the cultivation of rice was a conscious choice made by the artist. Obviously, this decision may be based on the preferences of the organisations ${ }^{5}$ which utilised these paintings in their advertisement, but it may also refer to the consciousness of the Hokkaido people. In any case, the lack of motifs referring to rice in the pictures drawn by the celebrated interpreter of the emotions of the Hokkaido people clearly conflicts with the message communicated in the early post-war period elementary school and high school textbooks approved by the Ministry of Education. Here, the official narrative describing the successful introduction of rice cultivation plays a central role in the pages or paragraphs dedicated to Hokkaido. $^{6}$

As far as the ideas concerning the peculiar characteristics of the Hokkaido people or Dosanko - a term literally referring to a Hokkaido born child - during the early post-war decades are concerned, the description provided by Nagai (Professor of Hokkaido University born in Tokyo) and Okaji (Professor of Hokkaido University of Education born in Shiga) can be taken as a starting point. Besides discussing the Hokkaido-specific vocabulary and way 
to express one's feelings, for example, this publication also pays attention to the appearance and temperament of Hokkaido people. When explaining why the physical attributes of the dosanko do not significantly differ from those of people living in Honshu, the authors emphasise the young history of Hokkaido and refer to studies comparing people who had migrated to Hokkaido and the population of their original home regions. When explaining the local manners and customs, the authors describe Hokkaido as a cocktail of people or a melting pot of Japan where individuals and groups from various parts of Japan are mixed together. Yet, they are ready to argue that the rough nature and history of reclamation hold some explanatory value when analysing the so-called frontier spirit and the kind-heartedness of the dosanko (Nagai and Okaji 1962: 62-101). The reliability of these claims is insignificant from the perspective of the current study. The point worth noticing here is the existence of the widely shared conception concerning the peculiarity of the people born, raised and living in Hokkaido at the beginning of the 1960s. This conception has later turned out to be enduring. Namely, the term of dosanko is still in use and many of the attributes associated with it have remained unchanged (Seaton 2016: 55).

When Seaton discusses the contemporary images of the nature of dosanko, he brings forth the absence of Ainu from the narrative describing the roots of modern-day Hokkaido inhabitants' nature. In other words, besides the rice or lack of it, also the existence Ainu could have challenged Hokkaido's suitability to the canon of Nihonjinron literature emphasising the uni-racial and homogenous composition of the Japanese. However, their existence was simply ignored, together with other minority groups incorporated during the colonial period, when emphasizing homogeneity (Seaton 2016: 55; Siddle 1997: 26; Yoshino 2004: 251-253). Obviously, the existence of Ainu was still known by Japanese. When Nagai and Okaji (1962: 1-4) begin their book by describing the Hokkaido-related symbols that are known by the Japanese, they list Ainu next to wilderness, poplar trees, lily of the valley, stock farms and silos.

\section{PECULIAR INSTITUTIONS, SENSE OF OTHERNESS AND LOCAL PRACTICES}

The third stage, called institutional shaping, refers to the development of informal and formal institutions that maintain the image of the region. The model suggests that these institutions are needed to produce and reproduce 
other shapes and regional consciousness, and they may exhibit regional or local practices, or be formal social, political, economic or administrative organizations (Paasi 1986: 126; Paasi 2009: 135). Because the expansion of the number of such institutions is considered significant, and because Hokkaido formed an exception to the Japanese administrative system where organizations functioned in a particular policy field and their mandate covered the whole country, attention can be first paid on the emergence and development of the post-war Hokkaido development system. Within this system, the boundaries between various ministries and government agencies were taken down for the sake of administering and developing a territory with physical borders (Koiso and Yamazaki 2007: 12).

The assimilation of the status as a "normal" prefecture at the beginning of the post-war period could be considered an end of Hokkaido's peculiar position among the regional entities within Japan. However, the enactment of the Hokkaido Development Law (1950), and the establishment of the Hokkaido Development Agency (1950), and the Hokkaido Development Bureau (1951), can be seen as a continuance of Hokkaido's unique legal and administrative standing. While the history of the region consisted of periods of Matsumae rule and the short lived Ezo-Republic — which was established and destroyed during the final act of the Meiji Restoration - the making of Hokkaido really started from the establishment of the Bureau of Colonial Affairs in 1869. This organisation was in charge of the colonisation of Hokkaido until 1882, when it was disbanded. The first, at least partially failed, attempt was succeeded by a short period during which Hokkaido was divided into three prefectures. Yet, a more stable situation was achieved only after the Hokkaido Agency was established in 1886 and it began to direct the reclamation and development activities (Saunavaara 2014: 135-137).

Next to the development policies, guided by two fifteen-year plans during the first half of the 20th century, Hokkaido's position as a part of the local government system and the local people's position as the citizens of Japan, evolved as well. Hokkaido was not an exception to the pre-war practice where heads of the prefectures were nominated by the central government. Yet the special laws that governed Hokkaido gave its executives more authority than governors possessed elsewhere. The rights and duties of people living in Hokkaido also differed from those in other parts of the state. ${ }^{7}$

The occupation authorities who assumed power after the unconditional surrender were committed to decentralisation and reform of the local governance system. The new Constitution and the Local Autonomy Law of 1947 were major building blocks for a system that recognised Hokkaido as one 
of the fully-fledged prefectures. Interestingly, the 1947 law still contributed to Hokkaido's peculiarity discourse as the northernmost prefecture was referred to with a character 道 or "dō." Thus, Hokkaido still stands out as one of the abnormal prefectures, together with Tokyo (referred to as 都 or "to") and Osaka and Kyoto (referred to as 府 or "fu"), which are not referred to with a regular character of 県 or "ken." Due to the legislative changes, reforms such as universal suffrage in all elections, and the possibility determine the governor in popular elections, were applied to Hokkaido as well. However, the development of unique administrative institutions and the emergence of peculiar regional interest groups affecting the voting behaviour of the local electorate were soon to highlight the differences between Hokkaido and the rest of Japan.

The prelude to a complex process leading to the creation of the postwar Hokkaido development system was witnessed in the spring of 1947 when the Japanese Government decided to establish the Hokkaido Development Agency. These plans were against the will of the occupation authorities, who intervened and banned the creation of such an organisation. However, the perception concerning the necessity of a unit which would coordinate the comprehensive development of Hokkaido did not disappear and eventually the discordant occupiers accepted the Hokkaido Development Law that stipulated the establishment of the Hokkaido Development Agency (Banno 2003; Saunavaara 2014). Meanwhile, the Hokkaido electorate voted in socialist Tanaka Toshifumi as the popularly elected governor at a time when most of his colleagues represented conservative stances. Furthermore, the Hokkaido people gave exceptional support to regionally strong but nationally weak political parties representing the cooperative principle and the interest of the farming population (Saunavaara 2015: 157-161).

These narratives merged in the spring and summer of 1951 when Governor Tanaka beat the candidate supported by the united conservative front. Nevertheless, soon after the re-election of the socialist Governor, the conservative government amended the Hokkaido Development Law and established the Hokkaido Development Bureau. This process curtailed the power of the governor as various Hokkaido administrations were incorporated under the direct jurisdiction of the central government. Eventually, Governor Tanaka was re-elected in 1955 and the socialist continued to poll exceptionally well in Hokkaido even after major rearrangements in the Japanese political party field in 1955. This did not mean, however, that the party organisation would have been unusually strong in Hokkaido. On the contrary, from the very beginning, the success of the socialists in Hokkaido had been based on 
the strength of the labour unions, and many of those who voted for the party identified primarily with the union which they were affiliated (Saunavaara 2015: 163-164).

The significance of the labour unions was obvious in Hokkaido from the very beginning of the post-war period. The Hokkaido coal mines in particular formed the forefront of the workers' movement in Japan. The unionisation in the rest of Japan was not only lagging behind Hokkaido, but it also took a different form. The Hokkaido miners departed from the traditional model and formed a union organisation that was not confined to one mine or enterprise, but encompassed all mines in the region (Itabashi 1992: 162, 166; Moore 1983: 33-40, 44, 46; Takemae 2003: 312). The socialists also owed their post-1955 success to an organisation called the Hokkaido Farmers' League (Hokkaidō Nōmin Dōmei), which was the mother organization behind the farmers' party movement until 1952 . These parties were built on a cooperative principle and they were able to challenge the nationally dominant conservative and progressive parties in Hokkaido. After the collapse of the last independent party, the majority of the former supporters of the various Hokkaido-based Farmers' Parties found their way into the ranks of the Socialist Party (Saunavaara 2015: 156-159). The significant post-war political role of the Hokkaido Farmers' League is not surprising because its presence can be seen as a continuation of the pre-war activities of agricultural and cooperative organisations, incorporating a strong tradition of supervision by the agricultural administration and of association with the political parties (Babb 2005: 177-179, 186-187; Mulgan 2000: 39-43).

When the spatial structure is analysed through the form of the features of production, consumption and exchange, attention cannot only be paid to the Hokkaido Comprehensive Development Plans, the first of which covered years between 1952 and 1961. Although these documents were the forerunners to national-level plans first enacted in the 1960s, and clearly showed what the Hokkaido Development Agency viewed as a desired course in the development of Hokkaido, they were not the only factors contributing to the evolution of Hokkaido's position within the Japanese economy. On the contrary, the first plan lacked funding and its achievements were critically discussed among policy-makers and the general public during the second half of the 1950s (Koiso and Yamazaki 2007: 111-112, 118; Ōnuma 2004: 24; Yamazaki 2006: 71-74). Meanwhile, a great variety of measures defining the core of economic activities in Hokkaido had taken place well before these plans were even drafted. 
To understand these measures and the spatial arrangement of industries, the concept of regional industrial identity can be included in the analytical framework. The regional industrial identity can be examined as a social code that arises from the shared understandings of residents and external audiences about the suitability of a region for particular kinds of business activity. In addition to this, it influences decisions about where to locate investments. Therefore, the regional economic development does not depend only on actual natural, industrial and institutional resources but also on the perceptions of regional economies, including their capacities for future economic development, that observers, including both the residents of a region and external audiences, hold. Such perceptions are argued as deriving principally from understandings of the kinds of businesses that already exist and thrive in a region (Romanelli and Khessina 2005: 344-358).

When reflected against this kind of argument, it is less surprising that continuity from the pre-war and wartime period to the post-war period was a distinctive feature for Hokkaido's economic structure. While the general interest in Hokkaido's economic possibilities and its untapped natural resources peaked during the occupation period—not least because Japan had lost Karafuto and conquests in continental Asia - neither public actors in the form of the occupation authorities and the Japanese Government nor major private enterprises initiated any significant attempts to diversify Hokkaido's economy and industry. The three main themes that dominated the discussion on Hokkaido's contribution to post-war reconstruction both within the Japanese Government and within the GHQ/SCAP were agricultural production and land reclamation, the development of the coal industry, and immigration of new population. Yet the ideas concerning the rapid population increase, the existence of new land suitable for reclamation, and the importance of coal had already existed as the basis for economic policies concerning Hokkaido during the pre-war decades. The public policies reflected the traditional understanding of the key features of industrial activity in a region and strengthened the existing regional industrial identity. In the meantime, neither the investments of individual private enterprises nor the development of different fields of industry challenged the structure whereby Hokkaido mainly exported primary sector products to Japan's industrial heartland and imported manufactured goods with a higher degree of processing (Banno 2003: 146-147, 165; Kobayashi 2010: 27, 38, 46; Koiso and Yamazaki 2007: 13; Ōnuma 2004: 18, 23-24).

The institutionalisation model suggests that the significant institutions in relation to the conceptual and symbolic formation are those which shape and 
control the content of the everyday symbolic environment and experience. With regard to nation-states, the formal education supplied by schools is recognised as the most important factor. Education in geography and history are identified as particularly significant media for socialisation and social reproduction, as these subjects impart fundamental notions of the world, the control of space and its historical basis to children. In other words, these subjects give political content to socio-spatial entities and define the major dimensions of national territories (Paasi 1986: 128).

A small group of Hokkaido-related themes and discourses can be identified in the analysis of early post-war elementary school and high school textbooks describing the geography and history of Japan. Besides the previously mentioned distinctive emphasis on the narrative describing the successful process that made rice cultivation possible in Hokkaido, the exceptionally cold climate and its effects, the foreign model and practices in the development and agriculture of Hokkaido, the importance of Hokkaido coal and, for example, the fact that Hokkaido was not a suitable production area for silk, were repeatedly highlighted. ${ }^{8}$ These kinds of characteristics may be a part of what, for example, Moriyama Daidō, a famous photographer born in Osaka in 1938, has described as the "image of the north" that allured him from his elementary school days (Kim 2015: 348).

Besides textbooks, the institutionalisation model identifies the importance of literature in the creation of external and internal identity of regions (Paasi 1986: 129). Therefore, the analysis of Hokkaido's appearance in literature and the characteristics of circumstances for publishing and printing activities at the beginning of the post-war period are significant. The exceptionality of the latter was based on the effects of the war. The early prosperity of Hokkaido's publishing industry was based on the fact that almost all printing facilities in big cities in central and southern Japan had suffered war damages, many paper mills were located in Hokkaido and the poor transportation conditions hindered attempts to export paper to other islands. However, the period during which many prominent publishers temporarily re-located to Hokkaido remained short. At the beginning of the 1950s, the number of active companies in Hokkaido dropped and publications concerning agriculture and education regained their dominance among the volumes printed by the Hokkaido-based companies (Hokkaidō 1977: 1488-1489).

In her work focusing on the representation of Hokkaido in modern Japanese literature, Noriko Agatsuma Day (2012: 1-30, 186-190. See also Seaton 2016: 65.) concentrates on works which are set in Hokkaido. She observes differences in works authored by writers from the metropole and 
writers from Hokkaido and describes the existence of an ambiguous duality that derives from Hokkaido's position as an internal colony. Day argues that Hokkaido contributed to shaping national identity and national literature by being the "other" or "different" in contrast to what was described as being nationally or ethnically "authentic" Japan in this colonial literature. While mainly concentrating on the years between the 1880s and the 1930s, Day argues that the characteristics of Hokkaido's colonial representation are carried on through the post-war period. While not emphasising the wartime promotion of settler colonies in literature, Day mentions, for example, Takeda Taijun, who visited Hokkaido in 1946 and kept depicting Hokkaido in his works as an outside world that was different from traditional Japan. Meanwhile, Kaikō Takeshi's famous Robinson no matsuei (Descendant of Robinson), published in 1960, depicted a man's struggle in the wilderness of Hokkaido immediately after the end of Second World War. This work illustrated the disappointment and hardship of many immigrants moving to Hokkaido after the defeat, but it also resembled earlier works describing the destiny of those who went to Hokkaido at the beginning of the Meiji period.

While the wide readership formed the linkage between individual novels and short stories and consciousness concerning the regional characteristics of Hokkaido, the appearance of the concept of "Hokkaido literature" in the 1950s was a process that mainly affected the cultural and academic elites. Still, the emergence of the concept combining any literary works on Hokkaido and/or by Hokkaido-related writers and the concrete efforts to compile volumes of Hokkaido-related literary history and literary anthologies, can be understood as a part of the institutionalisation process defining and redefining the meaning of Hokkaido and its relation to the discourses of Japan and Japaneseness. Day concludes that the strong desire to collect Hokkaido-related literary works during the post-war decades exemplified the regret that literary works on Hokkaido - and possibly Hokkaido itself-had not received proper recognition from Tokyo (Day 2012: 1-30, 186-190).

The emergence of the notion of "Hokkaido photography" took place in the 1960s when historical photographs of Hokkaido were reinterpreted by post-war avant-garde artists. The artists studied the photographs of the early Meiji-period, which had originally been taken to support the intensive survey and systematic documentation of Hokkaido colonisation. They hailed these pictures, where the focus was not on the general features of landscapes but on the sites of modernisation, as the origin of documentary photography in Japan. Therefore, the pictures that had previously been distributed and displayed for the sake of reporting the development and promoting the migration to Hokkaido 
were now in the spotlight because of their aesthetic value. Nevertheless, according to Gyewon Kim, this kind of reframing eventually resulted in the romantic projection of the first colony as a remote exotic zone. Hokkaido stood for a land of miracle, just as the documentary photography of the north looked miraculous itself (Kim 2015: 348-349, 351, 354, 362-363).

The institutionalisation model also guides one to pay special attention to the mass media of the regions and especially the newspapers, which bear strong economic ties with their market areas, are normally significant in regional consciousness and engender shared experiences (Paasi 1986: 129). The role of the leading regional newspaper also appears to be highly significant in the context of Hokkaido. Namely, although its origin was in the wartime policy that had brought all newspapers appearing in Hokkaido together, ${ }^{9}$ the rapid development of Hokkaido Shimbun took place during the first post-war decades. As new branch offices in different parts of Hokkaido were opened and the circulation and number of pages increased, it soon became a nationally recognised actor and a regionally dominant media organisation. Hokkaido's remote location added to the importance of Hokkaido Shimbun because it took two to three days to deliver any of the three major national newspapers from Tokyo to readers in different parts of Hokkaido. This situation remained until 1959 when the printing of Yomiuri Shimbun, Asahi Shimbun and Mainichi Shimbun began in Hokkaido. Besides the smaller local newspapers, the hegemonic position of Hokkaido Shimbun was also challenged by organisations representing other media technologies. While Hokkaido Broadcasting (HBC), which started radio broadcasting in 1952 and television broadcasts five years later, brought along diversity in and competition between mass media organisations, it did not separate the regional producers and consumers of media (Hokkaidō 1977: 1481-1487).

\section{REDEFINING THE MEANING OF HOKKAIDO, ITS PAST AND RELATIONSHIP WITH OTHER REGIONS}

The fourth stage of the model refers to a situation where an entity is accepted as part of the regional system and the broader social consciousness. The establishment of a region has, however, different meanings on various spatial scales. It may refer, for instance, to the recognition of sovereignty of a state territory or the gaining of an administrative status or established role within a state or in a broader regional system. Yet it can also refer to the attainment of a peculiar identity, homogenising expectations concerning the region (Paasi 
1986: 130; Paasi 2009: 136). It has become obvious that —no matter which one of the above mentioned definitions is used as a yardstick - the beginning of the Meiji period can be described as a major watershed in the historical establishment of Hokkaido. However, the beginning of the post-war period also consists of many significant features pointing toward the redefinition of the meaning of Hokkaido and its relationship with other parts of the regional system. Here, one should not get confused with the existence of manifold "establishments" of one region. While the established role is mentioned as the last phase, a region is still a continuous process without a completion or ending. Therefore, it is only natural that the conceptions concerning the existing or desired characteristics of Hokkaido which emerged during the immediate post-war years were eventually challenged.

The administrative status of Hokkaido as a prefecture became established during the first post-war decade and the main structures of the Hokkaido development system lasted until the beginning of the new millennium. The functions of the Hokkaido Development Agency were transferred to the new Ministry of Land, Infrastructure, Transport and Tourism in 2001, but the Hokkaido Development Bureau still exists today and the currently effective Hokkaido Comprehensive Development Plan was inaugurated in 2016. Meanwhile, the economic structure and role Hokkaido was occupying in the Japanese economy during the first post-war decade was soon challenged when Japan underwent the so-called rapid growth period. Although the importance of the primary sector remained greater in Hokkaido than in many other parts of Japan, the 1960s witnessed a radical decline in the number of people engaged in agriculture, forestry and fishery. A special emphasis was placed on the modernisation of the industrial structure and promotion of the heavy chemical industry, for example, but the growth rate of Hokkaido's industrial output did not surpass the national average but rather fell behind it. The enlargement of the tertiary sector overpowered other sectors, but could not keep up with the pace of national development (Ōnuma 2004: 21-29).

Besides these domestic processes, the regional economy had to adapt to growing international competition. At the beginning of the post-war period, the most significant change in the actual industrial production and the general perception concerning Hokkaido's economic possibilities was unquestionably bound to a major change in national energy policy at the end of the 1950s. The shift from domestic coal to imported oil had a huge effect on Hokkaido and wrecked the immediate post-war conception of a regional economy based on coal mining and food production. Despite the government engaging in a series of interventions designed to offer remedial assistance to a declining 
sector, mines were gradually closed during the following decades, businesses serving the coalmining communities disappeared, and these communities suffered severe depopulation although the population of Hokkaido was still slowly growing (Garside 2005: 186-203; Miyashita 2004: 135-155; Seaton 2010: 227-240).

The early post-war years also witnessed a redefinition of Hokkaido's role in the international context, as it was on the borderline of the bipolar Cold War world. The speculations concerning possible Soviet aggression against the island and repeated incidents between American and Soviet planes in Japan's airspace kept the people of Hokkaido alert. In addition to this, the US maintained troops in Hokkaido in permanent bases until the mid-1970s and the presence of the Japanese Self-Defence Forces remained exceptionally strong in the region (Irish 2009: 267-269; Sasaki 2015: 10, 158; Seaton 2016: 3). Thus, it has been suggested that, at least unofficially, the establishment of the Hokkaido region also had significance related to its location next to the Soviet Union (Koiso and Yamazaki 2007: 13; Sasaki 2015: 57). While the end of the Cold War altered this established geopolitical role, the continuous territorial dispute between Japan and Russia seems still to be the channel through which Hokkaido most often surfaces as a topic in international arenas.

Nevertheless, it is worth remembering that Hokkaido also attracted other kind of international attention at the beginning of the post-war period. The funds appropriated by the World Bank in the mid-1950s for the sake of the development of local agriculture (Koiso and Yamazaki 2007: 106, 109112), for example, can be considered an early sign of interest in the regional development of Hokkaido. However, the Sapporo Winter Olympics in 1972 were undoubtedly the single most important event demonstrating international recognition of Hokkaido and its well-established position as a highlydeveloped regional entity.

It has been shown above that many of the institutions that produce distinction and emphasise the peculiarity of Hokkaido even today had their origin in the early post-war years. Yet for the sake of underlying the nature of region and regional identity as a continuous process, changes in the ways of conceptualising and narrating the past of Hokkaido can be pointed out. The years preceding and succeeding the celebration of Hokkaido's centennial in 1968 witnessed the emergence of various institutions, which have played a major role in educating both locals and outsiders about the past of Hokkaido and the publication of works, which defined the conceptual and terminological parameters for the coming discussion on the history of Hokkaido (Mason 2012: 147; Seaton 2016: 66-67). 
The Hokkaido Historical Museum (Hokkaidō Kaitaku Kinenkan), funded and managed by the prefecture, opened its doors in the Nopporo Forest Park outside Sapporo in 1971 and initially displayed a typical version of the development narrative. Similarly, the nearby Hokkaido Centennial Tower (Hokkaidō Hyakunen Kinen Tō) that was completed already in 1970 represented what has been called the "dominant narratives" or "official history" of Hokkaido. The Historical Village of Hokkaido (Hokkaidō Kaitaku no Mura) formed the third part of this entirety describing the development narrative of the region. Meanwhile, the huge project of writing the New Hokkaido History (Shin Hokkaidō Shi), consisting nine volumes with each volume running to over 1,000 pages, formed another format through which to instill the official history (Mason 2012: 151, 155; Seaton 2016: 66-67; Siddle 1997: 28-29).

Nevertheless, the local historians of Hokkaido began to challenge this kind of "mainstream representation of Hokkaido" the 1970s onwards. Their counter narrative stressed the viewpoints of the colonised and criticised the development narrative by emphasising the nature of the process as colonisation and conquest. While receiving local success in the 1980s, the endeavour of the local historian was carried on by various foreign scholars publishing in English in the 1990s onwards (Seaton 2016: 2, 27, 34-35, 70). Mason's reading of the situation is a bid more pessimistic. She argues that the dominant narratives of Hokkaido's history that deny Hokkaido's status as a colony, remove the traces of Ainu and endorse the idea that the Japanese civilisation extended its technologically advanced skills to an undeveloped region, were first constructed during the Meiji period and are still adopted and adapted in a variety of sites, institutions and media in contemporary Japan (Mason 2012: $2-5,15,147-148,182-184$. See also Siddle 1997: 17.). Furthermore, in his study based on the analysis of junior high school history textbooks published in 2006, Henck (2015) concludes that the textbooks provide a highly sanitised version of events that disguises the colonisation and exploitation of Hokkaido by the Waijin.

\section{CONCLUSION}

The dominating and often contradicting tendencies of the early post-war Hokkaido were the continuing otherness, foreignness and distinctiveness from the rest of Japan, and the growing integration into the nation state. In other words, through various processes Hokkaido became more tightly connected to and more a part of Japan than ever before, but it clearly retained its peculiarity 
and was not simply a region or prefecture among the others. While this kind of regional status could easily be simplified just as a "natural" continuity, one should remember that the beginning of the post-war period was a whirlwind during which all aspects of Japanese society were contested and many fundamental structures of pre-war Japan were dissolved.

Less surprisingly, diversity is an epithet which can be attached to the concept of regional identity. Then again, the existence of an all-encompassing universally-shared regional identity in any given spatial and temporal context is an oxymoron and regional identity is still only one element in the complicated constellation of identifications that people normally possess. In the case of the early post-war period, the inhabitants of the region held various notions concerning the actual or preferred characteristics of Hokkaido, but the idea concerning the distinctiveness of the region seem to have been widely shared by both the local inhabitants and people living outside of it. In other words, the idea of Hokkaido's peculiarity was a deeply-rooted notion rather than just a tool that was used, for example, when the representatives of the people of Hokkaido attempted to secure maximum income transfers from the central government.

The often-mentioned sense of continuity suggests that the temporal othering was not a major element in the constitution of Hokkaido's immediate post-war regional identity. In other words, it was the rest of the Japan as a spatial other rather than the pre-war Hokkaido as a temporal other, which played the most significant role in the collective or community identity construction. However, this kind of conclusion may partly reflect the theoretical foundations of this particular study. Furthermore, the breakaways from the so-called official or dominant narratives vis-à-vis the Ainu in the 1970s, for example, can be understood as indicators of change emerging during the later decades.

Although the institutionalisation of regions model consists of steps, it is not - and it does not claim to be - a tool for emplotment which can be used to narrate the process through which regions come into being and evolved. Rather, it appears as a device helping one to perceive important processes and understand relations between them. As a flexible model it does not exclude much, but rather awakens its utiliser to acknowledge different political, economic, cultural and societal processes and their interconnectedness. Thus, it seems likely that many researchers can refer to it and acquire the features of the model which are the most fitting for the spatial and temporal context of their own research. Whether this is a strength or a weakness for a theory can be discussed. Although the conceptual flexibility may, in the worst case, lead into ambiguity, the decomposition of the region(-building) based on 
the institutionalisation model can firm up the conceptual foundations of an analysis and pave the way for fruitful comparative studies where the complex processes in comparison are broken down into meaningful components.

\section{NOTES}

* Juha Saunavaara is an assistant professor at the Hokkaido University Arctic Research Center, Japan. He earned his MA and PhD at University of Oulu, Finland (History) and University of Turku, Finland has granted him with a title of docent (specialisation: Japanese Studies, especially contemporary history). While preparing this article, he taught at the University of Oulu Department of History, hold a position as the Academy of Finland Postdoctoral Researcher and visited Hokkaido University Public Policy School. His past and current research fields include regional development of Hokkaido and other northern regions, relations and cooperation between Arctic and non-Arctic actors, democratisation and Japan's post-war political history. He has published various peer-reviewed journal articles and chapters in edited volumes representing the fields of Japanese and Asia-Pacific Studies, Arctic studies, international relations, and history. $\mathrm{He}$ is a Finnish national, who has a deep personal and professional commitment to Hokkaido.

1 The studies of Richard Siddle (1997), Brett L. Walker (2001) and Michele M. Mason (2012), all of which are utilised as valuable sources, can be recommended for those interested especially in the role of Ainu in the history of Hokkaido.

2 These islands are located roughly 20 and $50 \mathrm{~km}$ (about 12 and 31 miles, respectively) west of the northern peak of Hokkaido.

3 Referred as Chishima in Japanese.

4 G. Blakeslee, IDACFE, CAC-302, 28 December 1944, Japan and Territorial Problems: The Kurile Islands, 2-A-91. The occupation of Japan - U.S. Planning documents 19421945, ed. Iokibe, M. (Kobe: Congressional Information Service and Maruzen).

5 For example, Hokkaido Tourism Federation, Japan Railway, and Sapporo Railway Administration Bureau.

6 This analysis is based on following textbooks: Tochi to ningen. Watashitachi no seikatsu (3). Monbushō, 1947; Kikō to seikatsu. Watashitachi no seikatsu (4). Monbushō, 1948; Shakaika 5-nen: kōgyō to seikatsu. Gakkō tosho kenkyūkai, Gakkō tosho kabushiki kaisha, 1950. Monbushō kenteizumi kyōkasho; Shakaika 5-nen: mura no seikatsu - machi no seikatsu. Gakkō tosho kenkyūkai, Gakkō tosho kabushiki kaisha, 1950. Monbushō kenteizumi kyōkasho; Kōdō gakkō jinbun chiri (jō), Iimoto Nobuyuki, Kōgakusha 1951. Monbushō kenteizumi kyōkasho; Kōdō gakkō jinbun chiri (ka), Iimoto Nobuyuki, Kōgakusha 1951. Monbushō kenteizumi kyōkasho; Jinbun chiri, Tanaka Keiji, Nihon Shoin 1951. Monbushō kenteizumi kyōkasho; Gendai nihon no naritachi $(J \overline{)})$, Wakamori Tarō. Jitsugyō no Nihon Sha. Monbushō kenteizumi kyōkasho; Gendai nihon no naritachi (ka), Wakamori Tarō. Jitsugyō no Nihon Sha. Monbushō kenteizumi kyōkasho; Jinbun chiri - Shūteihan, Tanaka Keiji, Nihon Shoin 1952. Monbushō kenteizumi kyōkasho; Shin nihonshi, Ienaga Saburō, Sanseidō Shuppan, 1952. Monbushō kenteizumi kyōkasho. 
7 For example, those inhabitants of Hokkaido who met the general requirements gained the right to vote and elect their representatives in the national Diet only in 1902-a decade after the rest of Japan. The application of the Conscription Law of 1873, on the other hand, took decades to cover all of Hokkaido. Banno 2003: 30-31; Day 2012: 17; Irish 2009: 217; Steiner 1965: 45.

8 This analysis is based on the textbooks introduced in Footnote 6.

9 The policy that aimed at the amalgamation of all competing actors within one prefecture as one dominating entity was not limited to mass media. In the case of Hokkaido, the results of this overpowering approach can be seen, for example, in the unification of all dairy factories in 1941. Hokkaidō 1977: 256-259; Nakahara 2004: 63-85.

\section{REFERENCES}

Babb, J. 2005. Making farmers conservative: Japanese farmers, land reform and socialism. Social Science Japan Journal 8 (2): 175-195, https://doi.org/10.1093/ssjj/jyi037.

Banno, A. 2003. Hokkaidō Kaihatsu Kyoku to ha Nanika. GHQ Senryōka ni okeru Nijū Gyōsei no Hajimari. Sapporo: Jurōsha.

Blaxell, V. 2009. Designs of power: The "Japanization" of urban and rural space in colonial Hokkaidō. The Asia-Pacific Journal 35-2-09. http://japanfocus.org/-VivianBlaxell/3211 (accessed 28 November 2016).

Bukh, A. 2010. Japan's national identity and foreign policy: Russia as Japan's 'other'. London and New York: Routledge.

. 2012. Constructing Japan's 'northern territories': Domestic actors, interests, and the symbolism of the disputed islands. International Relations of the Asia-Pacific 12 (3): 483-509, https://doi.org/10.1093/irap/lcs008.

Bull, J. 2013. Ōhashi Kazuyoshi and the transition of Karafuto into Sakhalin. In Borders and transborder processes in Eurasia, ed. Sevastinov, S. et al, 133-149. Vladivostok: Dalnauka.

. 2015. Occupation-era Hokkaido and the emergence of the Karafuto repatriate. In Voices from the Shifting Russo-Japanese Border, ed. Paichadze, S. and Seaton, P., 63-79. London and New York: Routledge.

Compel, R. 2006. New facts about the early postwar Japan and Okinawa. Hosei University International Fund Foreign Scholars Fellowship Reports 12.

Day, N. A. 2012. The Outside Within: Literature of Colonial Hokkaido. Unpublished PhD diss., University of California. http://escholarship.org/uc/item/9xk0f3p7\#page-1 (accessed 28 November 2016).

Fujino, K. and Asada, H. 1982. Sengo no Hokkaidō Dōseihen: Hokkai Taimusu Shahen. Sapporo: Hokkai Taimasu.

Garcia-Alvarez, J. 1998. Substate nation-building and geographical representations of 'the Other' in Galicia, Spain (1860-1939). Finisterra XXXIII 65, 117-128.

Garside, W. R. 2005. A Very British Phenomenon? Industrial Politics and the Decline of the Japanese Coal Mining Industry since the 1950s. Australian Economic History Review 45 (2): 186-203, https://doi.org/10.1111/j.1467-8446.2005.00134.x. 
Hamin, E. M. and Marcucci, D. J. 2008. Ad hoc rural regionalism. Journal of Rural Studies 24 (4): 467-477, https://doi.org/10.1016/j.jrurstud.2008.03.009.

Hansen, P. 2014. Hokkaido's frontiers: Blurred embodiments, shared affects and the evolution of dairy farming's animal-human-machine. Critique of Anthropology 34 (1): 48-72, https://doi.org/10.1177/0308275X13510186.

Henck, N. 2015. Japan's junior high school history textbooks and the colonisation of Hokkaidō. Electronic Journal of Contemporary Japanese Studies 15 (2). http:// www.japanesestudies.org.uk/ejcjs/vol15/iss2/henck.html\#_ednref36 (accessed 28 November 2016).

Hiraku, T. 2011. Sengo no Hokkaidō Kaihatsu: Taisei no Seiritsu Keika to Chiiki Kadai he no Torikumi. Sapporo: Hokkaidō shuppan kikaku sentaa.

Hokkaidō. 1977. Shin Hokkaidō Shi: dai 6 kan, Tsūsetsu 5. Sapporo. . 2016. Shinboru. http://www.pref.hokkaido.lg.jp/overview/symbol.htm (accessed 20 July 2016).

Hokkaidōjin. 2016. Hokushin no hata to tomo ni. http://www.hokkaido-jin.jp/issue/ sp/200603/sp_01.html (accessed 28 November 2016).

Irish, A. B. 2009. Hokkaido: A history of ethnic transition and development on Japan's northern island. Jefferson: McFarland \& Company.

Itabashi, M. 1992. Kussetsu shita no Hokkaidō no kōgyō kaihatsu: Senzen no Mitsui Bussan to Hokutan Nikkō. Sapporo: Hokkaidō Shimbunsha.

Jaakson, R. 2000. Supra-national spatial planning of the Baltic Sea region and competing narratives for tourism. European Planning Studies 8 (5): 565-579, https://doi. org/10.1080/713666424.

Kamata, T. 2012. Kuriyagawa Kenichi - Hokkaidō wo Dezain Shita Otoko. Sapporo: Hokkaidō Shimbunsha.

Kim, G. 2015. Reframing "Hokkaido photography": Style, politics, and documentary photography in 1960s Japan. History of Photography 39 (4): 348-365, https://doi. org/10.1080/03087298.2015.1112532.

Kobayashi, Y. 2010. Hokkaidō no keizai to kaihatsu: Ronten to kadai. Sapporo: Hokkaidō Daigaku Shuppankai.

Koiso, S. and Yamazaki, M. 2007. Sengo Hokkaidō Kaihatsu no Kiseki - Taidan to Nenpyō de Furikaeru Kaihatsu Seisaku 1945-2006. Sapporo: Hokkaiō Kaihatsu Kyōkai.

Macleod, G. 1998. In what sense a region? Place hybridity, symbolic shape, and institutional formation in (post) modern Scotland. Political Geography 17 (7): 833-863, https:// doi.org/10.1016/S0962-6298(98)00041-9.

Mason, M. 2012. Dominant narratives of colonial Hokkaido and Imperial Japan: Envisioning the periphery and the modern nation-state. New York: Palgrave Macmillan, https://doi.org/10.1057/9781137330888.

Metzger, J. 2013. Raising the regional Leviathan: A relational-materialist conceptualization of regions-in-becoming as publics-in-stabilization. International Journal of Urban and Regional Studies 37: 1368-1395, https://doi.org/10.1111/1468-2427.12038.

Miruku Rando Hokkaidō. 2016. http://www.milkland-hokkaido.com/top/ (accessed 28 November 2016).

Miyashita, H. 2004. Sekitangyō. In Hokkaidō Sangyōshi, ed. M. Ōnuma. Sapporo: Hokkaidō Daigaku Tosho Kankōkai. 
Moore, J. 1983. Japanese workers and the struggle for power 1945-1947. Madison: University of Wisconsin Press.

Morris-Suzuki, T. 1995. The invention and reinvention of "Japanese culture." The Journal of Asian Studies 54 (3): 759-780, https://doi.org/10.2307/2059450.

Mulgan, A. G. 2000. The politics of agriculture in Japan. New York: Nissan Institute/ Routledge.

Nagai, Y. and Okaji, I. 1962. Hokkaidō. Tokyo: Chūō Kōronsha.

Nakahara, J. 2004. Rakunō. In Hokkaidō Sangyōshi, ed. M. Ōnuma. Sapporo: Hokkaidō Daigaku Tosho Kankōkai.

Ōnuma, M. 2004. Sōron. In Hokkaidō Sangyōshi, ed. M. Ōnuma. Sapporo: Hokkaidō Daigaku Tosho Kankōkai.

Paasi,A. 1986. The institutionalization of regions: A theoretical framework for understanding the emergence of regions and the constitution of regional identity. FENNIA 164 (1): 105-146, https://doi.org/10.11143/9052.

1991. Deconstructing regions: Notes on the scales of spatial life. Environment and Planning A 23: 239-256, https://doi.org/10.1068/a230239. .2009. The resurgence of the 'region' and 'regional identity': Theoretical perspectives and empirical observations on regional dynamics in Europe. In Globalizing the regional, regionalizing the global, ed. Fawn, R. Cambridge: Cambridge University Press, https://doi.org/10.1017/CBO9781139087339.006.

Romanelli, E. and Khessina, O. M. 2005. Regional industrial identity: Cluster configurations and economic development. Organization Science 16 (4): 344-358, https://doi. org/10.1287/orsc. 1050.0131 .

Sasaki, T. 2015. Japan's postwar military and civil society. London, New Delhi, New York, and Sydney: Bloomsbury.

Saunavaara, J. 2014. Postwar development of Hokkaido: The U.S. occupation authorities' local government reform in Japan. Journal of American-East Asian Relations 21 (2): 134-155, https://doi.org/10.1163/18765610-02102004.

.2015. Multilevel relations in Japanese political parties at the beginning of the postwar period: Hokkaido as a case study. Contemporary Japan 27 (2): 131-148.

Seaton, P. 2010. Depopulation and financial collapse in Yūbari: Market forces, administrative folly, or a warning to others? Social Science Japan Journal 13 (2): 227-240, https:// doi.org/10.1093/ssjj/jyp045.

Seaton, P. A. 2015. Memories beyond borders: Karafuto sites of memory in Hokkaido. In Voices from the shifting Russo-Japanese border, ed. S. Paichadze and P. Seaton. London and New York: Routledge. . 2016. Local history and war memories in Hokkaido. Abingdon: Routledge.

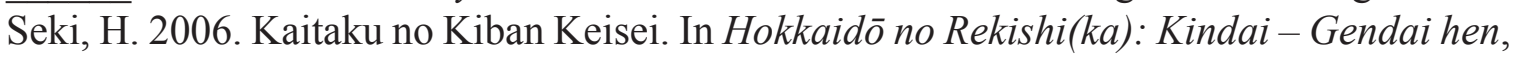
ed. H. Seki, H. et al. Sapporo: Hokkaidō Shimbunsha.

Siddle, R. 1997. Ainu: Japan's indigenous people. In Japan's minorities. The illusion of homogenity, ed. Weiner, M. London: Routledge.

2014. Race, resistance and the Ainu of Japan. Abindon: Routledge.

Steiner, K. 1965. Local government in Japan. Stanford: Stanford University Press.

Takemae, E. 2003. The Allied occupation of Japan. New York: Continuum.

Togo, K. 2005. Japan's foreign policy 1945-2003. Leiden - Boston: Brill. 
Walker, B. L. 2001. The conquest of Ainu lands: Ecology and culture in Japanese expansion 1590-1800. Berkeley: University of California Press.

Yamazaki, M. 2006. Kokudo Kaihatsu ni jidai-Sengo Hokkaidō wo Meguru Jichi to Tōchi. Tokyo: Tōkyō Daigaku Shuppankai.

Yoshino, K. 2004. The nihonjinron: Thinking elites ideas of Japanese uniqueness. In Race, ethnicity and migration in modern Japan, vol. 1, ed. Weiner, M. London and New York: Routledge Curzon Library of Modern Japan.

Zimmerbauer, K., Suutari, T. and Saarteenoja, A. 2012. Resistance to the deinstitutionalization of a region: Borders, identity and activism in a municipality merger. Geoforum 43: 1065-1075, https://doi.org/10.1016/j.geoforum.2012.06.009. 